\title{
Analysis on the Effect of Stair for Aseismic Performance of Base- Isolated Structure under Near-fault Ground Motions
}

\author{
Pingping Fan ${ }^{1, ~ a ~}$, Zhongtie $\mathrm{Wu}^{2, b}$ \\ ${ }^{1}$ School of Civil Engineering, Lanzhou Institute of Technology, Lanzhou. China \\ ${ }^{2}$ School of Civil Engineering, Northwest University for Nationalities. Lanzhou. 730050, China \\ afanpingping1984@163.com, bwuzhongtie1982@163.com
}

\begin{abstract}
Keywords: near-fault ground motions; stair; base-isolated structure; aseismic performance Abstract. In order to study the aseismic performance of base-isolated structures considering stair under near-fault ground motions, two base-isolated structure models were established in this paper, which one considered the effect of stair and another didn't. four near-fault ground motions and four far-fault ground motions from the Chi-Chi earthquake of Taiwan were selected as input excitation, two models are done the time history analysis by numerical analysis software Matlab2010. By contrast with the calculation results of two models each other, the effect of stair on aseismic performance of base-isolated structure under two kinds of ground motions was studied, the change trend of aseismic performance of two base-isolated structure models under near-fault ground motions was discussed. The results show that the deformation of upper structure of base-isolated structures is reduced obviously considering the effect of stair under near-fault ground motions and far-fault ground motions, the story shear force ratio of base-isolated structure is decreased significantly, the aseismic effect is better, the aseismic performance of base-isolated structures improves well. The effect of stair for the aseismic performance of base-isolated structures is low under near-fault ground motions, but it has significance in safety and reliability of base-isolated structures.
\end{abstract}

\section{Introduction}

In recent years, many large earthquakes occurred in all the world, the intensity and distribution of it was wide, and most was near-fault ground motions. For example, the Northridge earthquake of America in 1994, Kobe earthquake of Japan in 1995, Chi-Chi earthquake of Taiwan in 1999 and Wenchuan earthquake of china in 2008.Because of containing the long period and big peak value of pulse, near-fault ground motions had great effect on structure [1,2], especially base- isolated structure, which had the long period and excellent performance under far-fault ground motions[3,4]. The analysis of earthquake damage for WenChuan and YuShu showed that the stairs were damaged seriously, which was only life path for people in earthquakes[5,6]. Meantime many researchers also found that the stair had great effect on seismic performance of frame structure[7,8]. Now, there were lots of studies of base-isolated structure, but little study has been carried on base-isolated structure of considering the stair. Based on a base-isolated structure, the influence of stair on the aseismic effect of base-isolated structure was mainly investigated under near-fault ground motions, and the effect of near-fault ground motions was studied for base-isolated structures considering stair and not considering in this paper.

\section{The selection and analysis of ground motions}

With rapid construction of the seismic network and development of the seismological observation technology, near-fault ground motions collected from many earthquakes are relatively rich. Compared with far-fault ground motions, the main features of near-fault ground motions are longer period, peak value which is significantly higher and the pulse-like waveform. In order to contrast the aseismic effect of analysis models under near-fault ground motions, this paper references the suggestion of ground motions records in ATC-40, and comprehensive considers the response spectrum, earthquake magnitude, fault distance, PGV/PGA, acceleration peak, predominant period of seismic waves, and adopts 8 seismic waves in four stations, which are TCU075, TCU102, CHY028 
and TCU067 from the Chi-Chi earthquake of Taiwan. These seismic waves include 2 near-fault common seismic waves, 2 near-fault pulse-like seismic waves and 4 far-fault seismic waves. The response spectrum and the parameters of seismic waves are shown in Fig. 1 and Table 1 respectively. When time history analysis is done, acceleration amplitude of seismic waves is adjusted to $400 \mathrm{~cm} / \mathrm{s}^{2}$, which is the acceleration peak of the rare earthquake of 8 degree $0.2 \mathrm{~g}$ in the Chinese Code for seismic design of buildings (GB50011-2010). Duration either includes the strongest part of the seismic record or is 5 to 10 times of the basic period of structure, so duration of the selected seismic waves is 40 seconds in the paper.

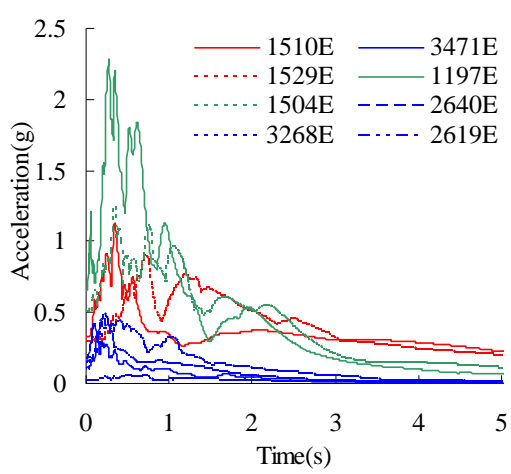

(a) The acceleration response spectrum

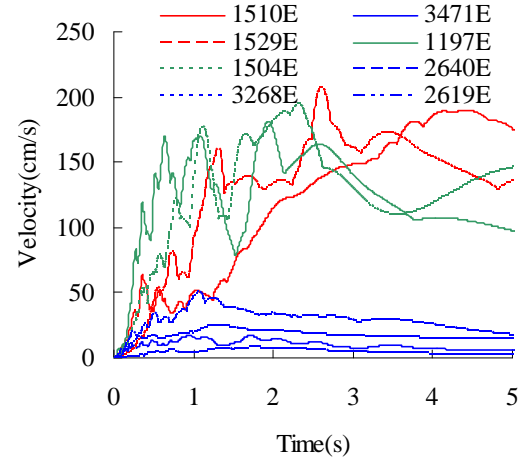

(b) The velocity response spectrum

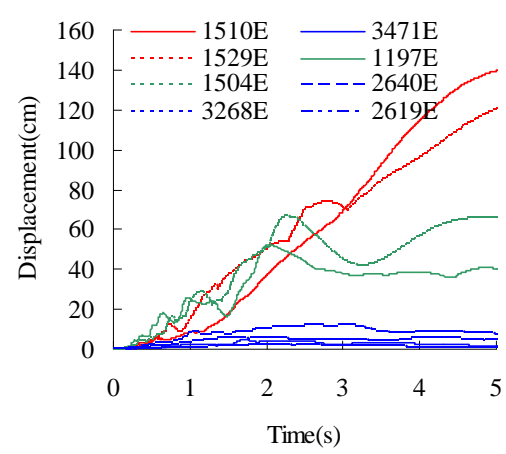

(c) The displacement response spectrum

Fig.1 The response spectrum of seismic waves

Table1 The parameters of earthquake waves

\begin{tabular}{|c|c|c|c|c|c|c|c|}
\hline Station & $\begin{array}{l}\text { seismic } \\
\text { waves }\end{array}$ & $\begin{array}{l}\text { earthquake } \\
\text { magnitude }\end{array}$ & $\begin{array}{c}\text { rupture } \\
\text { distance } \\
(\mathrm{km})\end{array}$ & $\begin{array}{l}\text { acceleration } \\
\text { peak(g) }\end{array}$ & $\begin{array}{c}\text { PGV/PGA } \\
\text { (s) }\end{array}$ & $\begin{array}{l}\mathrm{Tp} \\
(\mathrm{s})\end{array}$ & remarks \\
\hline TCU075 & $1510 \mathrm{E}$ & 7.62 & 0.9 & 0.329 & 0.276 & 0.36 & $\begin{array}{l}\text { near-faul } \\
\text { (pulsed) }\end{array}$ \\
\hline TCU075 & $3471 \mathrm{E}$ & 6.3 & 24.3 & 0.108 & 0.052 & 0.14 & far-faul \\
\hline TCU102 & 1529E & 7.62 & 1.5 & 0.297 & 0.389 & 0.72 & $\begin{array}{l}\text { near-faul } \\
\text { (pulsed) }\end{array}$ \\
\hline TCU102 & $2640 \mathrm{E}$ & 6.2 & 44.9 & 0.02 & 0.111 & 0.72 & far-faul \\
\hline CHY028 & 1197E & 7.62 & 3.1 & 0.653 & 0.117 & 0.28 & $\begin{array}{c}\text { near-faul } \\
\text { (no pulsed) }\end{array}$ \\
\hline CHY028 & 3268E & 6.3 & 32.1 & 0.151 & 0.101 & 0.4 & far-faul \\
\hline TCU067 & $1504 \mathrm{E}$ & 7.62 & 0.6 & 0.5 & 0.163 & 0.34 & $\begin{array}{c}\text { near-faul } \\
\text { (no pulsed) }\end{array}$ \\
\hline TCU067 & 2619E & 6.2 & 27.7 & 0.167 & 0.069 & 0.22 & far-faul \\
\hline
\end{tabular}

\section{Analysis model of isolation structure}

In this paper, firstly, two base-isolated structure models are established, the superstructures are reinforced concrete multistory frame considering the effect of stair and not considering, respectively. Secondly, the aseismic effect of two base-isolated structures is analyzed under near-fault and far-fault ground motions, and the change of aseismic effect of two models is researched under different seismic waves. The parameters of mass and stiffness of two models are listed in Table 2.The calculation models of base-isolated structure uses story shear model, the base-isolated structure equation can be written as :

$$
[M]\{\ddot{U}\}+[C]\{\dot{U}\}+[K]\{U\}=-[M]\left\{\ddot{U}{ }_{g}\right\}
$$


where $\{U\},\{\dot{U}\}$ and $\{\ddot{U}\}$ are horizontal relative displacement velocity and acceleration response respectively; $\left\{\ddot{U}_{g}\right\}$ is the acceleration of ground motion; $[M],[C]$ and $[K]$ are mass, damping and stiffness of base-isolated structure respectively.

Table 2 Mass and stiffness of models

\begin{tabular}{ccccc}
\hline \multirow{2}{*}{ number of story } & \multicolumn{3}{c}{ Model 1 } & Model 2 \\
\cline { 2 - 5 } & $\begin{array}{c}\text { mass } \\
(\mathrm{kg})\end{array}$ & $\begin{array}{c}\text { Stiffness of Y direction } \\
(\mathrm{kN} / \mathrm{m})\end{array}$ & $\begin{array}{c}\text { mass } \\
(\mathrm{kg})\end{array}$ & $\begin{array}{c}\text { Stiffness of Y direction } \\
(\mathrm{kN} / \mathrm{m})\end{array}$ \\
\hline 1 & 1069200 & 1301960 & 1100400 & 1751348 \\
2 & 1069200 & 844580 & 1100400 & 1201642 \\
3 & 1069300 & 752624 & 1100400 & 1098193 \\
4 & 1069200 & 717914 & 1100300 & 1050002 \\
5 & 1069200 & 676446 & 1100400 & 978937 \\
6 & 668100 & 480825 & 681300 & 682375 \\
\hline
\end{tabular}

\section{Numerical analysis results}

By numerical analysis software Matlab2010, 16 conditions of two models are done the time history analysis under 8 seismic waves. Considering the influence of Y direction (short direction of structure ) is bigger than $\mathrm{X}$ direction(long direction of structure ) of the stair in models, then the dynamic responses of $\mathrm{Y}$ direction of base-isolated structure are discussed in this paper using the time history analysis method. By the data treatment of time history analysis, this paper mainly discussed the change law and difference of some indexes of the different isolation structure models under different seismic waves, which include the absolute displacement, the story drift angle and the maximum of story shear force ratio. As are shown in Fig.2, Fig.3 and Fig.4, where dashed line and solid line are the base-isolated structure without stair (model 1) and with stair (model 2) respectively; the curves with tag are base-isolated structure under near-fault ground motions; the curves without tag are base-isolated structure under far-fault ground motions.

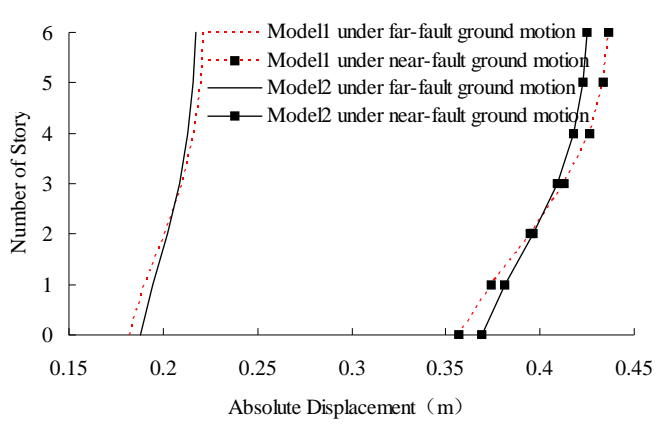

Fig.2 The change curves of absolute displacement

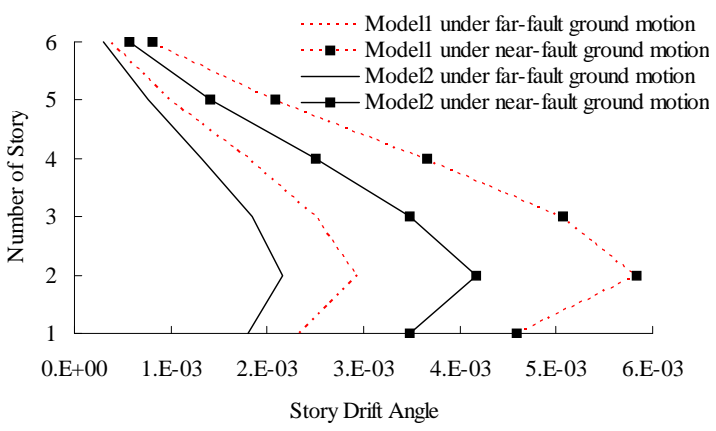

Fig.3 The change curves of story drift angle

Absolute displacement. The absolute displacement reflects the integral deformation of base-isolated structure, which is the each layer deformation of base-isolated structure relative to ground. The change curves, which are the mean absolute displacement of each layer of two models under different seismic waves, are demonstrated in Fig.2, Where 0 layer is isolation layer; stories of super structure are from 1 to 6 story. As is shown in Fig.2, the absolute displacements of isolation layer of two models are about $0.18 \mathrm{~m}$ for far-fault ground motions whereas they are about $0.36 \mathrm{~m}$ for near-fault ground motions, which is 2 times bigger than that of far-fault ground motions, the absolute displacement of other stories increased with the increasing of stories, and the absolute displacements of each stories of two models under near-fault ground motions are larger than that of under far-fault ground motions. In contrast to far-fault ground motions, the earthquake effect is stronger for base-isolated structure under near-fault ground motions, and the deformation and displacement of base-isolated structure increased evidently. For the near-fault and far-fault ground motions, the absolute displacement of two models increased with increasing of stories, the difference value 
between the absolute displacements of top floor and isolation layer of model 2 are $0.056 \mathrm{~m}$ and $0.030 \mathrm{~m}$, which of model 1 are $0.079 \mathrm{~m}$ and $0.040 \mathrm{~m}$. The ratios between the difference value of the absolute displacement of model 2 and model 1 are 0.71 and 0.75 . This shows that, the upper deformation of base-isolated structure is decreased significantly considering the effect of stair, it can be better to control the deformation of upper structure and beneficial to play aseismic performance of base-isolated structure.

Story drift angle. The story drift angle reflects the interlayer deformation of base-isolated structure, which is the ratio of each interlayer deformation and storey height of base-isolated structure. The change curves, which are the average of story drift angle of two models under different seismic waves, are demonstrated in Fig.3. As is shown in Fig.3, the variation of the story drift angle of two models is basically identical under near-fault and far-fault ground motions. The story drift angles of two models under near-fault ground motions were bigger than that under far-fault ground motions. And the maximum story drift angles of two models under near-fault ground are $5.84 \times 10^{-3}$ and $4.16 \times 10^{-3}$, whereas they are $2.93 \times 10^{-3}$ and $2.15 \times 10^{-3}$ for far-fault ground motions. the ratio between the maximum value of the story drift angle of two models under near-fault and far-fault ground motions is about 1.95.This shows that the interlayer deformation of base-isolated structure is stronger under near-fault ground motions, and the story drift angle of base-isolated structure increased obviously. For the near-fault and far-fault ground motions, the story drift angles of model 2 are bigger than those of model 1. The maximum difference value of the story drift angle of two models under near-fault ground motions and far-fault ground motions is $1.68 \times 10^{-3}$ and $0.78 \times 10^{-3}$, respectively. The result shows that the stair improves the stiffness of upper structure of base-isolated structure. It can effectively control the story drift angle, and its effect is more obvious under near-fault ground motions.

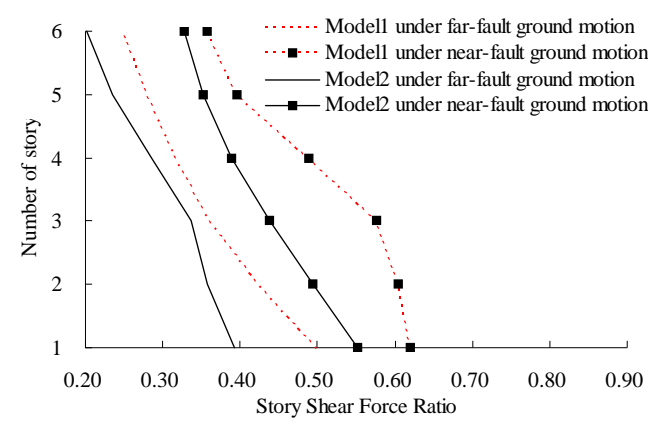

Fig.4 The change curves of story shear force ratio

Story shear force ratio. The story shear force ratio reflects the aseismic performance of base-isolated structure, which is the ratio of story shear force between base-isolated structure and non-isolated structure. The change curves, which are the average of story shear force ratio of two models under different ground motions, are demonstrated in Fig.4. As is shown in Fig.4, the change law of story shear force ratio of two models under near-fault ground motions consistent with far-fault ground motions. The maximum of story shear force ratio appears all in first story, the maximum of story shear force ratios of model 1 and model 2 under near-fault ground motions are 0.62 and 0.55 respectively, and the maximum of story shear force ratios of model 1 and model 2 under far-fault ground motions are 0.50 and 0.39 respectively. The maximum of story shear force ratio of the other stories decreased with the increasing of stories. Therefore, the story shear force ratios of two models under near-fault ground motions are larger than that under far-fault ground motions. This shows that, the story shear force ratio increase obviously under near-fault ground motions and the aseismic effect is relatively worse. For the near-fault and far-fault ground motions, the story shear force ratios of model 2 are smaller than that of model 1. It shows that, the effect of stair makes the story shear force ratio of base-isolated structure slow down significantly, the aseismic effect of base-isolated structure is improved. By Comparison, it can be found that the differential value of the maximum story shear force ratio of two models is 0.07 for near-fault ground motions, which is decreased by $11.2 \%$. This shows that, under near-fault ground motions, the stair also improve the aseismic performance of base-isolated structure well. 


\section{Conclusions}

The summarized findings are as follows:

1. Considering the effect of stair, the dynamic response of base-isolated structures changed obviously, the deformation of upper structure is reduced obviously, the story drift angles decrease, the story shear force ratio decreases significantly and it is beneficial to play the aseismic performance of base-isolated structures.

2. Comparison with far-fault ground motions, the upper deformation, the story drift angle and the story shear force ratio of base-isolated structure increase obviously under near-fault ground motions, aseismic effect of base-isolated structures decreased significantly, it is unfavorable to play the aseismic performance of base-isolated structures.

3. It is not considering the effect of stair for aseismic performance of base-isolated structures in common base-isolated structures design, story shear force ratio is relatively high, the base-isolated structures design relatively conservative. The conclusion of this paper can be reference for safety assessment of base-isolated structures design.

\section{Acknowledgments}

This work was financially supported by the youth science and technology innovation project of Lanzhou Institute of Technology (Grant No. 15K-008), the Fundamental Research Funds for the Central Universities (FRFCU) (Grant No. 31920150019) and Talent Introduction of Scientific Research Project of Northwest University for Nationalities (Grant No. xbmuyjrc201405).

\section{References}

[1] Dixiong Yang, Yan Zhao. Effects of rupture forward directivity and fling step of near-fault ground motions on seismic performance of base-isolated building structure. Acta Seismologica Sinica. Vol. 32(5)( 2010), p. 579-587.(In Chinese)

[2] Miao Han, Yanling Duan, Huan Sun. Shaking table test on influence of near-fault ground motions on seismic responses of base-isolated buildings. World Earthquake Engineering. Vol. 29(3)(2013), p. 22-26. (In Chinese)

[3] Dixiong Yang, Yan Zhao, Gang Li. Influence analysis of motion characteristics of near-fault ground motions on seismic responses of long-period structures. Journal of Disaster Prevention and Mitigation Engineering.27(2)( 2007) , p. 133-140. (In Chinese)

[4] Miao Han, Yanling Duan, Huan Sun, Wen Sheng. Influence of characteristics parameters of near-fault ground motions on the seismic responses of base-isolated structures. China Civil Engineering Journal.46(6)( 2013) , p. 8-13. (In Chinese)

[5] Liang Shen,Bingkang Liu, Yuzhong Zhang, Jibo Wu. Typical Seismic Damage Analysis and Finite Element Calculation of Stair in Frame in Wenchuan Earthquake. Earthquark Resistant Engineering and Retrofitting.32(4)( 2010) , p.114-119. (In Chinese)

[6] Chi Ling, Aifu Sun, Shuang Hou, Jinping Ou. The Study on Seismic Damage of Staircase for Multiple Ages Buildings in Dujiangyan city. Journal of Dalian university of technology.49(5)(2009), p.776-780. (In Chinese)

[7] Yonggang Ding, Jianqiang Wang, Ming Zhang. Study on Mechanical Properties of Staircase in Different Type of Structures. World Earthquark Engineering.30(2)( 2014) , p.122-128. (In Chinese)

[8] Wangxi Zhang, Changyang Liu. Elastic-plastic Analysis of Typical Teaching Building in 5.12 Wenchuan Earthquake Disaster Area with Regard to the Influence of Stairs. Journal of Disaster Prevention and Mitigation Engineering.35(5) (2015), p.699-706. (In Chinese) 